\title{
Occupational radiation exposure and genetic polymorphisms in DNA repair genes
}

\author{
F. Zakeri ${ }^{1,2, *}$, M.R. Farshidpour ${ }^{2}$ and M.R. Rajabpour ${ }^{2}$ \\ ${ }^{1}$ Nuclear Science and Technology Research Institute, Tehran, Iran. \\ ${ }^{2}$ Iran Nuclear Regulatory Authority, Tehran, Iran.
}

Received: 25 January 2017 / Accepted: 26 July 2017

\begin{abstract}
Radiation sensitivity appears to be influenced by genetic polymorphisms in some DNA repair genes and individuals with low DNA repair capacity can be at increased risk of developing cancer. The aim of the present study was to determine the impact of gene polymorphisms on DNA damages in the form of micronuclei (MN) in circulating lymphocytes of interventional cardiologists (ICs), occupationally exposed to ionizing radiation. $\mathrm{MN}$ frequency was significantly higher in the ICs than in the controls $(27.7 \pm 17.2 \% \mathrm{vs}$. $8.0 \pm 2.6 \%, p<0.0005)$. MN values were higher in the ICs with exposure of $\geq 10$ years and $\geq 3 \mathrm{mSv}$ in comparison to the related referents. The analysis of different interactions showed significantly higher MN frequencies in ICs exposed to $\geq 10 \mathrm{mSv}$ carrying the variant-type XRCC3 241Met genotype compared to those of wild-type XRCC3 (Thr/Thr) genotype. In the ICs carrying both wild-type alleles for XRCC3 and MSH3 polymorphisms showed a significantly lower MN frequency compared to the exposed individuals with one or two variant alleles for XRCC3 and MSH3 polymorphisms. In conclusion, ICs showed significantly higher $\mathrm{MN}$ frequencies than in the control, and this effect was higher in individuals carrying the variant-type XRCC3 241Met genotype. These results not only show the need for improvement of safety and training programs for ICs but also may be helpful in developing amenable screening tests for identifying radiosensitive workers and applying suitable radiation protection job-specific strategies for effective dose reduction.
\end{abstract}

Keywords: occupational exposure / cytogenetic / DNA / genetic effect / radiation / low doses

\section{Introduction}

Radiation exposure causes a variety of DNA damages including single strand breaks (SSB) and double-strand breaks (DSB) leading to lethal events, cancers and non-cancers. There are specific pathways for the repair of different types of DNA damages such as base excision repair (BER), homologous recombination repair (HRR), non homologous endjoining (NHEJ), nucleotide excision repair (NER) and mismatch repair (MMR). Oxidative base damage and strand breaks induced by ionizing radiation are mainly repaired by BER, NHEJ and HRR pathways (Friedberg et al., 1995) but may also involve to a lesser extent MMR and NER. Therefore any defect in these pathways may cause radiation sensitivity and elevated cancer risk (Hu et al., 2001). Genetic polymorphisms in DNA repair genes may alter the functional properties of DNA repair enzymes and consequently influence inter-individual variation in DNA repair capacity and susceptibility to cancer (Lunn et al., 1999).

\footnotetext{
* Corresponding author: fzakeri@aeoi.org.ir
}

The cytokinesis-block micronucleus assay (CBMN) is a reliable method for detection of chromosome breakage and loss in human peripheral blood lymphocytes and also is a standardized technique for biodosimetry in radiation protection (Thierens and Vral, 2009). Micronuclei (MN) have been known as intermediate endpoints of carcinogenesis and a predictor of cancer (Fenech, 2006; Fenech et al., 2016). There are association studies that show the link between DNA repair gene polymorphisms and $\mathrm{MN}$ induction (Angelini et al., 2005). XRCC1 (X-ray cross-complementation group 1) has a role in BER, and XRCC3 (X-ray cross-complementation group 3 ) acts in the HRR pathway. Cells with mutation in XRCC1 and XRCC3 show increased and moderate sensitivity to ionizing radiation, respectively, therefore single nucleotide polymorphisms (SNPs) in these two genes are very important in radiation sensitivity (Angelini et al., 2005). Also a possible role for NER proteins such as Xeroderma pigmentosum; XP in the repair of some types of oxidative damage induced by ionizing radiation has been shown and polymorphisms in the XPD and XPG genes have been associated with lung and breast cancers (Angelini et al., 2005). 
MMR has a role in the repair of post-DNA replication base pairing errors by the MutS $\alpha$ complex (composed of the MMR proteins MSH2 and MSH6) or MutS $\beta$ complex (containing MSH2 and MSH3) (Angelini et al., 2005).

Invasive cardiology procedures can deliver high radiation doses to the staff capable of inducing significant health effects such as occurrence of higher DNA damages, cataracts and higher incidence of brain cancer (Zakeri et al., 2010). Due to the impact of radiosensitivity on enhanced DNA damage and risk of developing different types of cancer, there is a need for identifying sensitive individuals particularly in work environments where occupational exposure doses may be significant. Therefore in the present study, we investigated the potential links between genetic polymorphisms in genes XRCC1 Arg194Trp, XRCC3 Thr241Met, XPD Lys751Gln and MSH3 Ala1036Thr coding DNA repair enzymes in different pathways and the levels of DNA damage investigated by micronucleus assay in interventional cardiologists.

\section{Methods}

The present study included 129 subjects: 89 interventional cardiologists (58 males, $42.5 \pm 8.1$ years and 31 females, $39.6 \pm 6.0$ years) who worked in cardiac catheterization laboratories of heart hospitals, and 40 individuals (27 males, $41.93 \pm 9.46$ years and 13 females, $40.3 \pm 8.4$ years) working in the administrative departments of the same hospitals without radiation exposure as the control group.

All subjects in this study filled-in questionnaires included information about smoking habits, medical history, drug intake and diagnostic medical irradiation. They were healthy individuals without current infections and medications in the last 6 months, and were mostly non-smokers. All participants' rights were protected and written informed consent was obtained from all donors. The study protocol was approved by the national ethical committee and also conformed to the ethical guidelines of the World Medical Association (Declaration of Helsinki).

The official personal dosimetry records based on bimonthly film dosemeters were collected for each radiation worker for the last 1 and 5 years.

The micronuclei were prepared in cytokinesis blocked cells using cytochalasin B (Cyt-B Sigma) as suggested by (Fenech, 1993). Whole blood cultures were performed by adding $0.5 \mathrm{ml}$ blood to $4.5 \mathrm{ml}$ RPMI-1640 culture medium supplemented with $20 \%$ fetal calf serum, $100 \mathrm{UI} / \mathrm{ml}$ penicillin and $0.1 \mathrm{mg} / \mathrm{ml}$ streptomycin, $1.0 \%$ l-glutamine and $1.0 \%$ phytohemagglutinin (PHA) for mitogenic stimulation. Two separate cultures from each sample prepared and incubated at $37^{\circ} \mathrm{C}, 5 \% \mathrm{CO} 2$ for 72 hours. After 44 hours of incubation cytochalasin B $(6 \mu \mathrm{g} / \mathrm{ml})$ was added to the cultures to block cytokinesis. After collection of the cells by centrifugation, cells were treated with a hypotonic solution $(0.075 \mathrm{M} \mathrm{KCl})$ for $3 \mathrm{~min}$. After centrifugation and removal of the supernatant, the cells were fixed with a fresh mixture of methanol/acetic acid (3:1) (all materials purchased from Gibco BRL). After three times centrifugation and resuspension, slides were made under warm and humid conditions, air-dried and stained with 5\% Giemsa as previously described (Rastkhah et al., 2016).

To determine the total number of $\mathrm{MN}$ in binucleated cells, according to the IAEA handbook (EPR Biodosimetry IAEA,
2011) a total of 1000 binucleated cells with well-preserved cytoplasm ( 500 cells per replicate) were scored for each subject and the nuclear division index (NDI) was calculated.

Blood specimens were taken from all participants by using EDTA-containing tubes, and genomic DNA was extracted from peripheral blood by using QIAgen kit, Germany. All DNA materials were protected in $4{ }^{\circ} \mathrm{C}$ refrigerators for later analyses. Genetic polymorphisms were analyzed by polymerase chain reaction (PCR) and restriction fragment length polymorphism (RFLP) method. For each of the studied parameters, the appropriate primers were used to amplify the corresponding gene by PCR and the reaction products were digested by using the specific restriction enzymes (Fermentas, USA) that recognized and cut either the wild-type or variant sequence site. Information about primers sequence, annealing temperature, restriction pattern and restriction enzymes used for each genotyping assay are given in Table 1 . The digested PCR products were analyzed on $10 \%$ polyacrylamide gels and $4 \%$ ultra-pure agarose gel and stained with Gel red (Biotium, USA). Genotype results were confirmed by random repetition of $30 \%$ of the samples, and all uncertain results were rechecked with the same technique.

The SPSS package, version 17 was used for statistical analyses of the data. The data are shown as mean \pm SD. Because of the over-dispersed nature of the $\mathrm{MN}$ distribution, logarithmic transformation of data was used for analyses. The Student's $t$-test and $\chi 2$ analysis were used for evaluation of the differences between the means of the two continuous and noncontinuous variables, respectively. Multinomial logistic regression was used to test the existence of a different genotype distribution between controls and ICs. Different gene interactions were investigated with exposure doses, age, smoking, gender and time exposure (years). The data for more than two different groups were analyzed by ANOVA, $p<0.05$ was considered as the significant level for all analyses.

\section{Results and discussion}

The characteristics of the study groups are shown in Table 2. The genotype distribution at each locus in the total population was consistent with the Hardy-Weinberg equilibrium for the Caucasian population. There were no statistically significant differences between any genotypes or alleles in the control and exposed groups for XRCC1 Arg194Trp, XRCC3 Thr241Met and MSH3 Ala1036Thr (Tab. 2) except in the wild-type and variant genotypes for XPD Lys751Gln $(p=0.003)$.

The mean cumulative dose exposures during the 1 and 5 last years received by ICs were $3.5 \pm 3.4 \mathrm{mSv}$ and $11.1 \pm 10.0 \mathrm{mSv}$, respectively. They were occupationally exposed to ionizing radiation for $9.5 \pm 6.7$ years.

It has shown that the doses received by interventional cardiologists may well be above the annual limits of $20 \mathrm{mSv}$ proposed by ICRP. ICs are at high risk of posterior subcapsular cataracts and the risk increased with duration of activity but no clear relationship with workload was observed (Jacob et al., 2013). Approaches have developed in the European ELDO project for retrospective assessment of eye lens doses for interventional cardiologists that will be of great benefit for ongoing epidemiological studies (Domienik et al., 2016). In a 
Table 1. Details of PCR and RFLP procedures for each genotyping assay.

\begin{tabular}{|c|c|c|c|c|c|}
\hline Gene & SNPs & Primers 5'-3' & $\begin{array}{l}\text { Annealing } \\
\text { Temp }\left({ }^{\circ} \mathrm{C}\right)\end{array}$ & $\begin{array}{l}\text { Restriction } \\
\text { Enzymes }\end{array}$ & Fragment sizes (bp) \\
\hline$X R C C 1$ & Arg194Trp & $\begin{array}{l}\text { F: GCC AGG GCC CCT CCT TCA A } \\
\text { R:TAC CCT CAG ACC CAC GAG T }\end{array}$ & 62 & Pvu II & $\begin{array}{l}485(\mathrm{R} / \mathrm{R}) \\
396+89(\mathrm{~W} / \mathrm{W}) \\
485+396+89(\mathrm{R} / \mathrm{W})\end{array}$ \\
\hline$X R C C 3$ & Thr241Met & $\begin{array}{l}\text { F:GGT CGA GTG ACA GTC CAA AC } \\
\text { R:TGC AAC GGC TGA GGG TCT T }\end{array}$ & 60 & Hin1 II & $\begin{array}{l}315+140(\mathrm{~T} / \mathrm{T}) \\
210+140+105(\mathrm{M} / \mathrm{M}) \\
315+210+140+105(\mathrm{~T} / \mathrm{M})\end{array}$ \\
\hline MSH3 & Ala1036Thr & $\begin{array}{l}\text { F:TCT AAC AGG CAA GTA GGA AC } \\
\text { R:TAG CCA CAT TTA ATC CAT AAC }\end{array}$ & 52 & Hha I & $\begin{array}{l}138+87(\mathrm{~A} / \mathrm{A}) \\
225(\mathrm{~T} / \mathrm{T}) \\
225+138+87(\mathrm{~A} / \mathrm{T})\end{array}$ \\
\hline
\end{tabular}

Table 2. General characteristics and genotype distributions of studied genes in the ICS and control groups.

\begin{tabular}{|c|c|c|c|}
\hline & $\mathrm{ICs}^{\mathrm{a}}$ & Control & $p$ value \\
\hline \multicolumn{4}{|l|}{ Gender, n (\%) } \\
\hline Male & $58(65.2)$ & $27(67.5)$ & 0.48 \\
\hline Mean age, years \pm S.D. & $41.5 \pm 7.5$ & $41.4 \pm 9.0$ & 0.93 \\
\hline \multicolumn{4}{|l|}{ Smoking habits, n (\%) } \\
\hline Yes & $3(3.5)$ & $4(10.0)$ & 0.13 \\
\hline Mean time exposure, years \pm S.D. & $9.5 \pm 6.7$ & $13.8 \pm 7.7$ & 0.21 \\
\hline Mean last year exposure $\mathrm{mSv} \pm \mathrm{SD}$ & $3.5 \pm 3.4$ & - & \\
\hline Mean last five years exposure $\mathrm{mSv} \pm \mathrm{SD}$ & $11.1 \pm 10.0$ & - & \\
\hline Mean $\mathrm{MN}$ frequency $\pm \mathrm{SD}(\%)$ & $27.7 \pm 17.2(89)$ & $8.0 \pm 2.6(40)$ & $<0.0005$ \\
\hline Nuclear division index (NDI) & $1.7 \pm 0.1$ & $1.7 \pm 0.1$ & 0.32 \\
\hline XRCC1 codon $194, \mathrm{n}(\%)$ & & & 0.82 \\
\hline Wild: $T h r / T h r$ & $42(47.2)$ & $17(42.5)$ & \\
\hline Variant:Met/Met & $11(12.4)$ & $7(17.5)$ & \\
\hline Variant: $T h r / M e t$ & $36(40.4)$ & $16(40)$ & \\
\hline$X P D$ codon $751, \mathrm{n}(\%)$ & & & 0.003 \\
\hline Wild: Lys/Lys & $39(43.8)$ & $7(17.5)$ & \\
\hline Variant: $G \ln / G \ln$ & $16(18.0)$ & $17(42.5)$ & \\
\hline Variant: Lys/Gln & $34(38.2)$ & $16(40)$ & \\
\hline MSH3 codon $1036, \mathrm{n}(\%)$ & & & 0.4 \\
\hline Wild: Ala/ Ala & $8(9.0)$ & $1(2.5)$ & \\
\hline Variant $: T h r / T h r$ & $50(56.2)$ & $25(62.5)$ & \\
\hline Variant: Ala/ Thr & $31(34.8)$ & $14(35.0)$ & \\
\hline
\end{tabular}

\footnotetext{
${ }^{\text {a }}$ Interventional cardiologists.
}

study the estimated cumulative left and right eye lens dose ranged from 8 to $264 \mathrm{mSv}$ and 6 to $225 \mathrm{mSv}$, respectively and calculations showed annual eye lens doses sometimes exceeding the new ICRP annual limit of $20 \mathrm{mSv}$ (Farah et al., 2014).

$\mathrm{MN}$ frequency was significantly higher in the ICs than in controls $(27.7 \pm 17.2 \%$ ovs. $8.0 \pm 2.6 \%$ o $p<0.0005)$. This result agrees with several cytogenetic investigations by CBMN assay in radiation workers (Maluf et al., 2000; Aka et al., 2004; Dias et al., 2007). The MN frequency in interventional cardiologists with the mean cumulative radiation dose of $1.7 \pm 2.3 \mathrm{mSv}$ (range $0.2-8.3 \mathrm{mSv}$ ) over the last 6 months, was significantly higher than in clinical physicians; $19.7 \pm 7.8 \%$ vs. $13.5 \pm 6.3 \%$ o $p=0.0003$ (Andreassi et al., 2009). In another 

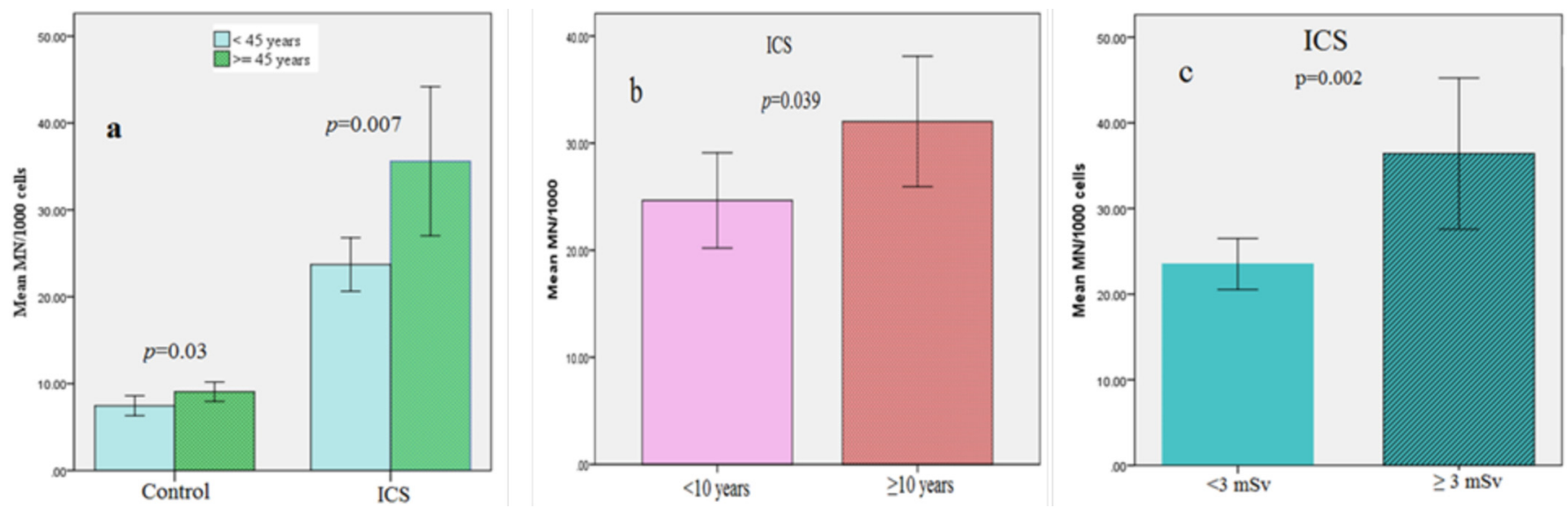

Fig. 1. MN frequencies in the study population subdivided by age (a); significantly higher MN frequencies were found in the older age groups ( $>45$ years) than in the younger age groups ( $<45$ years) in the both groups, time exposure year (b); MN values were significantly higher in the ICS group with time exposure of $>10$ years in comparison to $<10$ years $(p=0.039)$ and exposure status (c); significant difference in MN frequency was also observed between occupational radiation doses of $\geq 3 \mathrm{mSv}$ and $<3 \mathrm{mSv}$ during last year of exposure ( $p=0.002$ ).

study the mean frequencies of micronuclei in the 30 cardiology department workers (25.57-4.79\%o) and 30 radiology department workers $(21.90-4.23 \%$ ) were significantly higher than that in the 27 controls (10.78-1.47\%o) (Sakly et al., 2013).

The MN frequency in the 67 healthcare workers occupationally exposed to ionizing radiation below the permissible dose of $50 \mathrm{mSv} /$ year showed a significant higher $\mathrm{MN}$ frequency compared to the control group $(13.63 \pm 4.9 \%$ o vs. $6.52 \pm 4.21 \%, p<0.05)$. Also the $(\mathrm{C}-\mathrm{MN})$ frequency was significantly higher in the exposed subjects than in the controls $(9.04 \pm 4.57 \%$ ovs. $1.17 \pm 0.77 \%$ ) pointing to the clastogenic effects of radiation. There was a lack of data on individual physical doses of radiation in this study. However, the time of exposure to ionizing radiation had a significant effect on the level of MNs and C-MN (Bouraoui et al., 2013).

In our recent in vitro study blood samples from 16 healthy donors (eight males and eight females in two age ranges of 2034 and $35-50$ years) irradiated up to $4 \mathrm{~Gy}(0.25-4 \mathrm{~Gy})$ of gamma rays (with a dose rate of $0.83 \mathrm{~Gy} / \mathrm{min}$ ). The micronucleus assay was employed to obtain the frequencies of micronuclei and the data were used to construct the calibration curves for men and women in two age groups, separately. The results showed the average baseline frequency of $11.75 \pm 1.48 \%$ o (8-14) micronuclei for the donors in ages between $35-50$ years and after $0.25 \mathrm{~Gy}$ in vitro irradiation, the average frequency of $35.37 \pm 6.34 \%$ o (28-49) micronuclei was observed (Rastkhah et al., 2016).

Most micronuclei induced by ionizing radiation are formed of acentric fragments because they are the result of chromosome breakage that consequently may cause radiation sensitivity and genetic susceptibility to cancer. Other factors such as nutritional status, genotoxins and genetic predisposition, may influence $\mathrm{MN}$ induction and cause variable $\mathrm{MN}$ background frequency. However, the studied groups in this study are healthy individuals from the same city and culture and are socioeconomically matched, and this technique is used as a sensitive and validated technique for systematic biomonitoring of radiation workers exposed to low-doses of ionizing radiation (Thierens and Vral, 2009).
No statistically significant differences in $\mathrm{MN}$ frequencies were also observed between males and females in the ICs $(25.8 \pm 15.1 \%$ vs. $31.1 \pm 20.4 \% ; p=0.16)$ and in the control group $(7.7 \pm 2.6 \%$ vs. $8.6 \pm 2.6 \% ; p=0.36)$ respectively. However, MN frequency in the females was slightly higher than in the males in both groups. It has been reported that women have a $19-40 \%$ higher baseline micronucleus frequencies than men (Rastkhah et al., 2016).

Multiple regression analysis showed that age had a significant effect on the MN frequency in control group (standardized $\beta=0.313, p=0.049$ ), whereas the effects of age in ICs were not significant (standardized $\beta=0.199, p=0.062$ ). As shown in Figure 1a, significantly higher MN frequencies were found in the subgroups of older age ( $\geq 45$ years) than in the younger age group (<45 years) $(23.7 \pm 11.8 \%$ o $v s$. $35.6 \pm 22.9 \%, p=0.007$ in the ICs and $7.4 \pm 2.8 \%$ vs. $9.0 \pm 1.9 \% ; p=0.03$ in the control group). Forty five years were used for the age subdivision and for calculating the cumulative percentage. The increasing effect of age on background $\mathrm{MN}$ frequencies are due to the decline in DNA repair capacity and attributed to increased chromosome loss with age, related to X-chromosome (Thierens and Vral, 2009). The observed result in the control group is because of age. However, in the ICs it is also affected by the higher duration of work and the doses received.

Smoking status had not significant effects on $\mathrm{MN}$ frequency in both groups (in control: standardized $\beta=-0.007, p=0.964$ and in ICs: standardized $\beta=0.153, p=0.159$ ).

Multiple regression analysis showed that last year exposure $(\mathrm{mSv})$ (standardized $\beta=0.150, p=0.304)$ and last 5 year exposures $(\mathrm{mSv})$ (standardized $\beta=0.033, p=0.827)$ and occupational time of exposure (standardized $\beta=0.132$, $p=0.219$ ) had not significant effects on the MN frequency in the ICs.

After 10 years of study on 200 nuclear dockyard workers, an increased frequency of chromosomal aberrations and dose effect relationship were reported on the basis of accumulated dose (Evanse et al., 1979). In some other studies higher frequencies of $\mathrm{MN}$ and chromosomal aberration have been 
Table 3. MN frequencies in genotypes of different DNA repair genes polymorphisms the ICS and control groups.

\begin{tabular}{|c|c|c|c|c|c|c|c|c|}
\hline Gene & Codon & Genotype & $\begin{array}{l}\text { Control } \\
\mathrm{n}\end{array}$ & Mean $\mathrm{MN} \pm \mathrm{SD}$ & $p$ value & $\begin{array}{l}\text { ICS } \\
\mathrm{n}\end{array}$ & Mean $\mathrm{MN} \pm \mathrm{SD}$ & $p$ value \\
\hline$X R C C 1$ & 194 & Wild & 34 & $7.8 \pm 2.6$ & 0.39 & 77 & $28.6 \pm 18.3$ & 0.2 \\
\hline \multirow{2}{*}{$X R C C 3$} & \multirow[b]{2}{*}{241} & Wild & 17 & $7.5 \pm 3.0$ & \multirow[t]{2}{*}{0.174} & 42 & $24.3 \pm 13.6$ & \multirow{2}{*}{0.09} \\
\hline & & Variant & 23 & $8.3 \pm 2.3$ & & 47 & $30.7 \pm 19.5$ & \\
\hline$X P D$ & 751 & Wild & 7 & $7.2 \pm 2.1$ & 0.56 & 39 & $27.1 \pm 15.7$ & 0.99 \\
\hline \multirow{2}{*}{ MSH3 } & \multirow{2}{*}{1036} & Wild & 1 & 12.0 & \multirow[t]{2}{*}{-} & 8 & $25.0 \pm 22.1$ & \multirow{2}{*}{0.21} \\
\hline & & Variant & 39 & $7.9 \pm 2.6$ & & 81 & $27.9 \pm 16.8$ & \\
\hline
\end{tabular}

reported in people occupationally exposed to X-rays than in normal controls without a dose-dependent increase in yield as a function of duration of exposure (Zakeri and Assaei, 2004; Sari-Minodier et al., 2007). This can be explained by the fact that during long term exposure part of the DNA damage is not detected because of the death of lymphocytes.

By division of the ICs into time exposure sub-sets of less than, or more than, 10 years the results showed that MN frequencies were higher in the ICs with time exposure of $\geq 10$ years in comparison to $<10$ years $(32.0 \pm 18.2 \%$ o $v$. $24.6 \pm 15.9 \%, p=0.039$ ) (Fig. 1b) due to their higher exposure levels $(6.4 \pm 4.5 \mathrm{mSv}$ vs. $2.8 \pm 2.7 \mathrm{mSv}$, respectively).

As shown in Figure 1c significant difference in $\mathrm{MN}$ frequency was also observed between occupational radiation doses of $\geq 3 \mathrm{mSv}$ and $<3 \mathrm{mSv}$ during last year of exposure $(36.4 \pm 23.2 \%$ vs. $23.5 \pm 11.5 \%$, $p=0.002)$. However, for last five years of exposure there was no significant difference between radiation doses of $\geq 10 \mathrm{mSv}$ and $<10 \mathrm{mSv}(p=0.11)$, may be due to the unstable nature of the MN aberrations.

The radiation doses in the studied groups of interventional cardiologists have been routinely monitored by film badges they wore under lead aprons. However, it has been reported in ICRP (2011), that personal dosimeters are not used by some professionals or their use is irregular and as a consequence, occupational doses in several fluoroscopically guided practices are largely unknown.

As shown in Table 3, none of the polymorphisms was associated with $\mathrm{MN}$ frequency in the whole population. However, the 'variant' of the XRCC3 gene at $p=0.09$ is not far from significance.

Considering the XRCC3 codon 241 genotypes, significantly higher MN frequency was found in ICS exposed to $\geq 10 \mathrm{mSv}$ carrying the variant-type XRCC3 241Met alleles compared to those carrying wild-type XRCC3 (Thr/Thr) allele (exposed to $\geq 10 \mathrm{mSv}$ ) and also to the referent counterparts carrying either the variant or wild-type XRCC3 genotypes with exposure $<10 \mathrm{mSv}(40.5 \pm 24.0 \%$ vs. $22.1 \pm 16.4 \%$, $25.1 \pm 12.8 \%$, $25.1 \pm 14.2 \% ; F=4.5, p=0.002$ ) (Tab. 4).

The small sample size of individuals per category in our study is an important limitation that may affect the statistical power of findings. Therefore, larger scale studies are needed for assessing the interaction between genes and environmental factors and confirming these results.

As the XRCC3 gene acts in the homologous recombination repair pathway of DNA double strand breaks, this is an interesting result. The scaffolding protein XRCC3 is a paralog of the very important RAD51 gene involved in the first step of homologous recombination repair of DNA double-strand breaks. The XRCC3 Thr241Met polymorphism has been associated with an increase in DNA damage (Matullo et al., 2001; Au et al., 2003) although the reason is not clear. It has been reported earlier that the Met/Met variant of XRCC3 results in an increased frequency of micronuclei in workers exposed to ionizing radiation (Andreassi et al., 2009). The effect of the XRCC 3 codon 241 variants on the frequency of MN may be due to the chromosome loss caused by malsegregation and centrosome amplification and relatively low DNA repair capacity (Yoshihara et al., 2004; Lindh et al., 2006). XRCC3 acts in the HRR pathway for correct chromosome segregation and stability (Wildinga et al., 2005). XRCC3 241Met causes a deficiency in the structure of the DNA repair protein and therefore in the HRR pathway and the repair mechanism may shift toward NHEJ, with chromosome instability and repair deficiency (Song et al., 2015).

Further analysis of different interactions between genotypes revealed by ANOVA analysis showed significantly higher MN frequencies in the following subsets:

- Control individuals with one variant allele for XRCC1 and XRCC3 polymorphisms compared to controls carrying both wild-type alleles for XRCC1 (Arg/Arg) and XRCC3 (Thr/Thr) polymorphisms (8.6 $\pm 2.5 \%$ v vs. $7.0 \pm 2.8 \%$, $p=0.04$ ), (Fig. 2).

- Control individuals carrying both variant alleles for XRCC3 241Met and XPD 751Gln polymorphisms compared to controls with one variant alleles for XRCC3 and XPD polymorphisms $(8.7 \pm 2.2 \%$ vs. $7.1 \pm 2.8 \%$, $p=0.04$ ) (Fig. 3). Apparently, a combination of adverse genotypes may increase the risk of DNA damage. XPD in NER repair pathway senses the distortion caused by a base and is involved in the removal of cyclopyrimidine dimers, photoproducts produced by UV light and bulky lesions in human DNA induced by environmental physical or chemical agents (Friedberg et al., 1995). XPD gene defects are involved in genetic disorders of cancer-prone syndrome xeroderma pigmentosum complementation group D, trichothiodystrophy and Cockayne syndrome. The possible role for XPD in the repair of oxidative damages induced by ionizing radiation has been also reported (Angelini et al., 2005). In our study, the relatively 
Table 4. Associations of different DNA repair gene polymorphisms with the MN frequencies in the ICs group subdivided by exposure status.

\begin{tabular}{|c|c|c|c|c|c|}
\hline \multicolumn{2}{|c|}{ Cardiology staff } & \multicolumn{2}{|c|}{ Exposure (last year) } & \multicolumn{2}{|c|}{ Exposure (last 5 years) } \\
\hline & & $<3 \mathrm{mSv}$ & $\geq 3 \mathrm{mSv}$ & $<10 \mathrm{mSv}$ & $\geq 10 \mathrm{mSv}$ \\
\hline \multirow{4}{*}{$\begin{array}{l}X R C C 1 \\
\text { codon } 194\end{array}$} & $\mathrm{~W}(\mathrm{n})$ & $\begin{array}{l}23.6 \pm 12.0^{*} \\
(54)\end{array}$ & $40.2 \pm 24.5(23)$ & $\begin{array}{l}25.5 \pm 14.2 \\
(53)\end{array}$ & $\begin{array}{l}35.3 \pm 24.1 \\
(24)\end{array}$ \\
\hline & $\mathrm{M}(\mathrm{n})$ & $\begin{array}{l}22.3 \pm 5.2 \\
(6)\end{array}$ & $\begin{array}{l}21.6 \pm 5.9^{* *} \\
(6)\end{array}$ & $\begin{array}{l}22.5 \pm 5.4 \\
(8)\end{array}$ & $\begin{array}{l}21.0 \pm 5.7 \\
(4)\end{array}$ \\
\hline & $p$ value & \multicolumn{2}{|c|}{$\begin{array}{c}p<0.0005^{*} \\
p=\mathbf{0 . 0 4}^{* *}\end{array}$} & \multicolumn{2}{|c|}{ NS } \\
\hline & $\mathrm{W}(\mathrm{n})$ & $\begin{array}{l}22.2 \pm 9.5^{*} \\
(33)\end{array}$ & $\begin{array}{l}32 \pm 22.5 \\
(9)\end{array}$ & $\begin{array}{l}25.1 \pm 12.8 \\
(31)\end{array}$ & $\begin{array}{l}22.1 \pm 16.4 \\
(12)\end{array}$ \\
\hline \multirow{2}{*}{$\begin{array}{l}X R C C 3 \\
\text { codon } 241\end{array}$} & $\mathrm{~V}(\mathrm{n})$ & $\begin{array}{l}25.0 \pm 13.6^{* *} \\
(27)\end{array}$ & $\begin{array}{l}38.4 \pm 23.8 \\
(20)\end{array}$ & $\begin{array}{l}25.1 \pm 14.2 \\
(30)\end{array}$ & $\begin{array}{l}40.5 \pm 24.0 \\
(17)\end{array}$ \\
\hline & $p$ value & \multicolumn{2}{|c|}{$\begin{array}{l}p=0.001^{*} \\
p=0.01^{* *}\end{array}$} & \multicolumn{2}{|c|}{$F=4.5 \quad p=0.002^{\mathrm{a}}$} \\
\hline \multirow{3}{*}{$\begin{array}{l}X P D \\
\text { codon } 751\end{array}$} & $\mathrm{~V}(\mathrm{n})$ & $\begin{array}{l}23.4 \pm 10.9 \\
(32)\end{array}$ & $\begin{array}{l}36.6 \pm 25.4 \\
(18)\end{array}$ & $\begin{array}{l}25.0 \pm 11.9 \\
(32)\end{array}$ & $\begin{array}{l}33.7 \pm 25.9 \\
(18)\end{array}$ \\
\hline & $p$ value & \multicolumn{2}{|c|}{$\begin{array}{c}F=3.48 \\
p=0.019^{\mathrm{a}}\end{array}$} & \multicolumn{2}{|c|}{ NS } \\
\hline & $\mathrm{W}(\mathrm{n})$ & $\begin{array}{l}16.0 \pm 9.2 \\
(6)\end{array}$ & $\begin{array}{l}52.0 \pm 32.5 \\
(2)\end{array}$ & $\begin{array}{l}17.8 \pm 9.0^{*} \\
(5)\end{array}$ & $\begin{array}{l}37.0 \pm 34.6 \\
(3)\end{array}$ \\
\hline \multirow{2}{*}{$\begin{array}{l}\text { MSH3 } \\
\text { codon } 1036\end{array}$} & $\mathrm{~V}(\mathrm{n})$ & $\begin{array}{l}24.3 \pm 11.5 \\
(54)\end{array}$ & $\begin{array}{l}35.2 \pm 22.8 \\
(27)\end{array}$ & $\begin{array}{l}25.8 \pm 13.5 \\
(56)\end{array}$ & $\begin{array}{l}32.8 \pm 22.0 \\
(25)\end{array}$ \\
\hline & $p$ value & \multicolumn{2}{|c|}{$\begin{array}{c}F=5.54 \\
p=0.002^{\mathrm{a}}\end{array}$} & \multicolumn{2}{|c|}{$p=0.044^{*}$} \\
\hline
\end{tabular}

W: wild type, V: variant type. $*$ or $* *$ Mean $\pm \mathrm{SD} v s$. bold variable is significant at the 0.05 level by least significant difference (LSD) post hoc test. ${ }^{a}$ ANOVA $p$ value among groups.

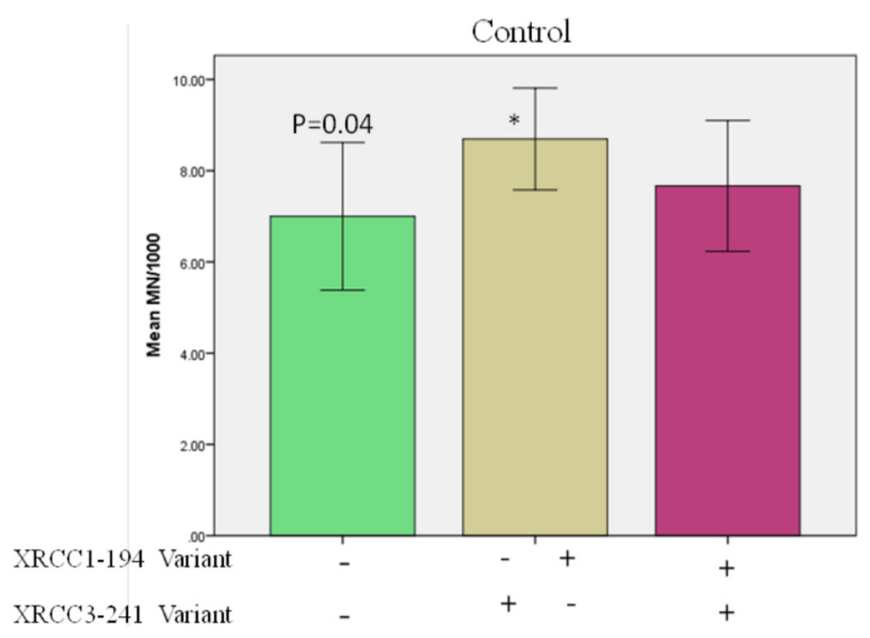

Fig. 2. Interactive effects of $X R C C 1$ codon 194 and $X R C C 3$ codon 241 genes in the control group. Control individuals with one variant allele for XRCC1 and XRCC3 polymorphisms showed significantly higher $\mathrm{MN}$ frequencies compared to controls carrying both wild-type alleles for XRCC1 and XRCC3 polymorphisms. .Significant at $p=0.04 v s$. homozygous wild (--) genotypes (ANOVA analysis). $(--)$ : both wild genotypes, $(-+$ or +-$)$ : one variant genotypes and $(++)$ : homozygous variant genotypes. small sample size of subjects having this genotype may affect the result, however, the strength of this study is the analysis of a study group of individuals exposed to significant occupational radiation doses.

- However, in the ICs, individuals carrying both wild-type alleles for XRCC3 (Thr/Thr) and MSH3 (Ala/Ala) polymorphisms showed a significantly lower MN frequency or a better repair compared to exposed individuals with one or two variant alleles for XRCC3 and MSH3 polymorphisms $\quad(16.0 \pm 9.2 \%$ vs. $27.1 \pm 15.7 \%$ and $29.7 \pm 18.8 \%$ o, $F=3.28, p=0.04$ ) (Fig. 4).

This observed association in the radiation exposed individuals is the first report and needs to be confirmed in other studies with larger population exposed to radiation. However, one possible explanation for this result is that combination of these wild type genotypes and their effects on DSBs repair and correction of mispaired bases during DNA replication errors may contribute to the lower MN frequencies. MMR initially corrects single base-pair mismatches and small insertion-deletion loops during replication recognized by the MSH2-MSH6 heterodimer (MutSa) and larger insertiondeletion loops are recognized by the MSH2-MSH3 heterodimer (MutSb) (Berndt et al., 2007). Song et al. (2006) reported an increased ovarian cancer risk with single nucleotide polymorphisms in MSH6 and MSH3. The 


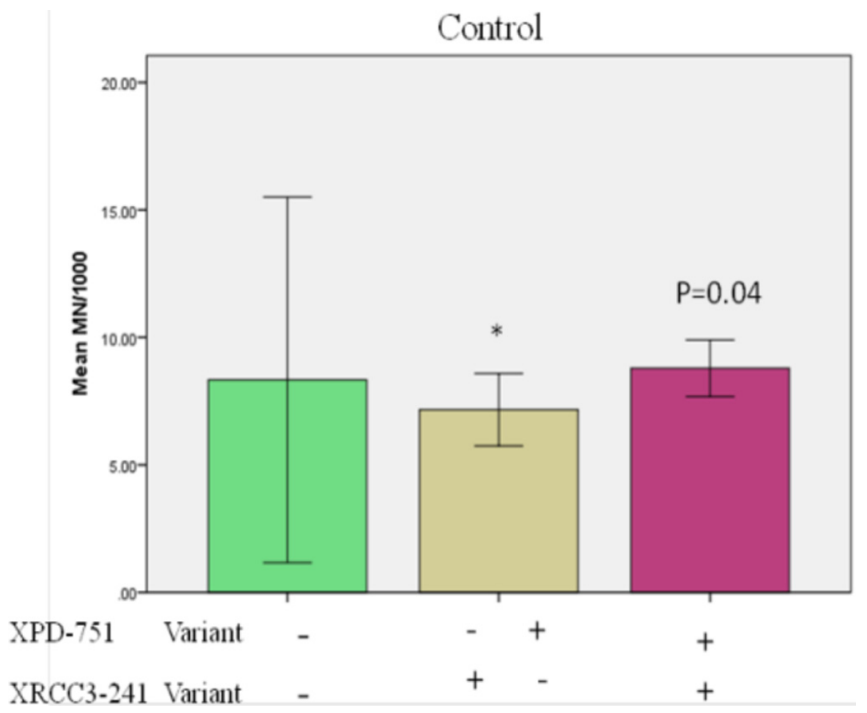

Fig. 3. Interactive effects of $X P D$ codon 751 and $X R C C 3$ codon 241 genes in the control group. Control individuals carrying both variant alleles for XRCC3 241Met and XPD 751Gln polymorphisms showed significantly higher $\mathrm{MN}$ frequencies compared to controls with one variant alleles for XRCC3 and XPD polymorphisms. * Significant at $p=0.04 v s$. homozygous variant $(++)$ genotypes (ANOVA analysis). $(--)$ : both wild genotypes, $(-+$ or +-$)$ : one variant genotypes and $(++)$ : homozygous variant genotypes.

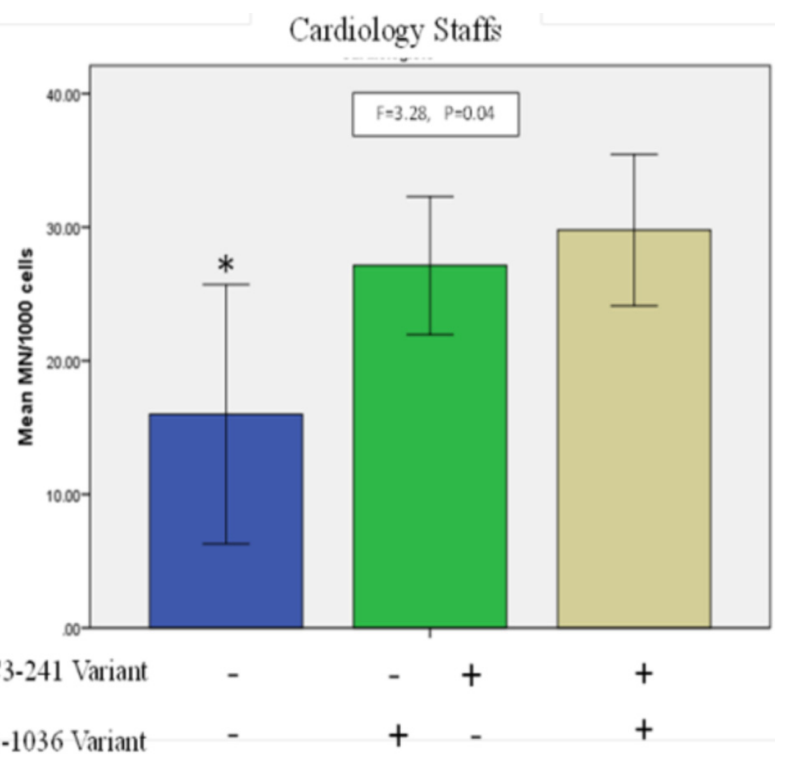

Fig. 4. Interactive effects of XRCC3 codon 241 and MSH3 codon 1036 genes in the ICS group. Individuals carrying both wild-type alleles for XRCC3 and MSH3 polymorphisms showed a significantly lower $\mathrm{MN}$ frequency compared to exposed individuals with one or two variant alleles for XRCC3 and MSH3 polymorphisms. *Significant at $p=0.04 v s$. one variant genotypes $(-+$ or +-$)$ and at $p=0.01 \mathrm{vs}$. homozygous variant $(++)$ genotypes. $(--)$ : both wild genotypes, $(-+$ or +-$)$ : one variant genotypes and $(++)$ : homozygous variant genotypes.

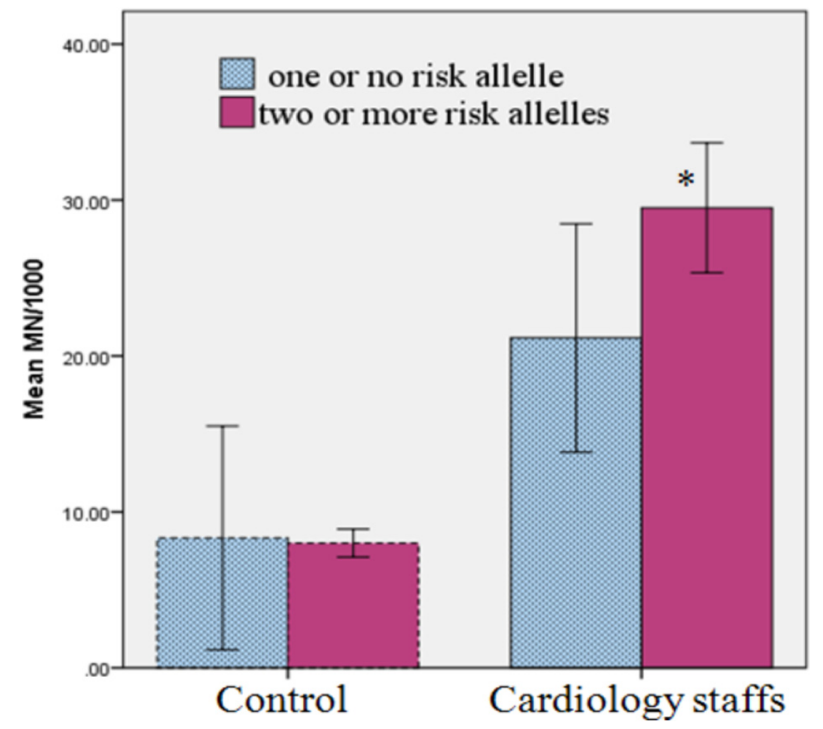

Fig. 5. MN frequency of individuals with one or no risk allele compared to those with two or more risk alleles in ICS and control groups. *Significant at $p=0.01 v s$. one or no risk allele.

polymorphism in MSH3 and p53 codon 72 may increase the risk for prostate cancer (Hirata et al., 2008).

Individuals carrying polymorphisms of genes in two important DNA repair pathways (XRCC1 of BER, XRCC3 of HRR; XRCC 3 of HRR and XPD of NER; XRCC 3 of HRR and MSH3 of MMR) are very likely affected in their repair of specific DNA lesions involving these different repair pathways. This is especially of importance if the inducing agent consists of ionizing radiation inducing multiple types of DNA lesions.

- Multiple regression analysis of the ICs revealed the presence of risk allele $\geq 2$ as a significant predictor of $\mathrm{MN}$ frequency (standardized $\beta=0.269, p=0.01$ ). As shown in Figure 5 in the ICs individuals with two or more risk alleles compared to those with one or no risk allele showed significantly higher MN frequencies $(29.5 \pm 17.4 \%$ vs. $21.1 \pm 15.1 \%, p=0.01$ ) (Fig. 5).

In conclusion, our results indicate a relationship between $\mathrm{MN}$ frequency as a marker of genotoxic effect and genetic polymorphisms in genes coding for DNA repair enzymes. Our results showed that even low doses of ionizing radiation exposure could have genotoxic effects and that genetic polymorphisms in susceptible individuals occupationally exposed to low doses of ionizing radiation might contribute to the increased DNA damage. This study may be helpful in developing genetic screening tests to identify radiosensitive workers. Identification of radiosensitive workers may help in providing better medical surveillance programs and job-specific strategies to reduce dose. Additional protections, more restricted dose limits, especial education and training should be made available for sensitive individuals working in places where occupational radiation exposures may be significant. Moreover, it is unethical and unwise to put radiosensitive individuals in situations where they might receive a large dose (ICRP Publication 118, 2012). However, for better understanding of 
the effects of genetic polymorphisms on $\mathrm{MN}$ induction further larger population studies with considering individual DNA repair capacity are recommended. The present study confirmed the usefulness of $\mathrm{MN}$ analysis for cytogenetic biomonitoring of radiation workers and increased levels of MN in lymphocytes of interventional cardiologists showed the need for improvement of their safety and training programs.

Acknowledgment. This study was funded by Iran Nuclear Regulatory Authority. The authors would like to thank the volunteers who donated blood samples for this study and Mr. M.J. Ahmadpour for his technical assistance.

\section{References}

Aka P, Mateuca R, Buchet JP, Thierens H, Kirsch-Volders M. 2004. Are genetic polymorphisms in OGG1, XRCC1 and XRCC3 genes predictive for the DNA strand break repair phenotype and genotoxicity in workers exposed to low dose ionising radiations? Mutat. Res.556: 169-181.

Andreassi MG, Foffa I, Manfredi S, Botto N, Cioppa A, Picano E. 2009. Genetic polymorphisms in XRCC1, OGG1, APE1 and XRCC3 DNA repair genes, ionizing radiation exposure and chromosomal DNA damage in interventional cardiologists, Mutat. Res. 666: 57-63.

Angelini S, Kumar R, Carbone F, Maffei F, Forti GC, Violante FS, Lodi V, Curti S, Hemminki K, Hrelia P. 2005. Micronuclei in humans induced by exposure to low level of ionizing radiation: influence of polymorphismsin DNA repair genes, Mutat. Res. 570: $105-117$.

Au AA, Salama SA, Sierra-Torres CH. 2003. Functional characterization of polymorphisms in DNA repair genes using cytogenetic challenge assays, Environ. Health Perspect. 111: 1843-1850.

Berndt SI, Platz EA, Fallin MD, Thuita LW, Hoffman SC, Helzlsouer KJ. 2007. Mismatch repair polymorphisms and the risk of colorectal cancer, Int. J. Cancer 120: 1548-1554.

Bouraoui S, Mougou S, Drira A, Tabka F, Bouali N, Mrizek N, Elghezal H, Saad A. 2013. A cytogenetic approach to the effects of low levels of ionizing radiation on the exposed Tunisian hospital workers, Int. J. of Occup. Med. Environ. Health 26(1): 144-154.

Dias FL, Antunes LMG., Rezende PA, Carvalho FES, Silva CMD, Matheus JM, Oliveira Jr JV, Lopes GP, Pereira GA, Balarin MAS. 2007. Cytogenetic analysis in lymphocytes from workers occupationally exposed to low levels of ionizing radiation, Environ. Toxicol. Pharmacol. 23: 228-33.

Domienik J, Farah J, Struelens L. 2016. Validation of ELDO approaches for retrospective assessment of cumulative eye lens doses of interventional cardiologists - results from DoReMi project, J. Radiol. Prot. 36(4): 736-745.

EPR Biodosimetry IAEA. 2011. World Health Organization, International Atomic Energy Agency, Cytogenetic dosimetry: applications in preparedness for and response to radiation emergency.

Evanse HJ, Buckton KE, Hamilton GE, Carothers A. 1979. Radiationinduced chromosomal aberrations in nuclear dockyard workers, Nature 277: 531-534.

Farah J, Struelens L, Auvinen A, Jacob S, Koukorava C, Schnelzer M, Vanhavere F, Clairand I. 2014. Application of the ELDO approach to assess cumulative eye lens doses for interventional cardiologists, Radiat. Prot. Dosim. 164(1-2): 84-88.

Fenech M. 1993. The cytokinesis-block micronucleus assay: a detailed description of the method and its application to genotoxicity studies in human populations, Mutat. Res. 285: 35-44.
Fenech M. 2006. Cytokinesis-block micronucleus assay evolves into a "cytome" assay of chromosomal instability, mitotic dysfunction and cell death, Mutat. Res. 600: 58-66.

Fenech M, Knasmueller S, Bolognesi C, Bonassi S, Holland N, Migliore L, Palitti F, Natarajan AT, Kirsch-Volders M. 2016. Molecular mechanisms by which in vivo exposure to exogenous chemical genotoxic agents can lead to micronucleus formation in lymphocytes in vivo and ex vivo in humans, Mutat. Res. 770: $12-25$.

Friedberg EC, Walker GC, Siede W. 1995. DNA Repair and Mutagenesis. Washington DC: ASM Press.

Hirata H, Hinoda Y, Kawamoto K, Kikuno N, Suehiro Y, Okayama N, Tanaka Y, Dahiya R. 2008. Mismatch repair gene MSH3 polymorphism is associated with the risk of sporadic prostate cancer, J. Urol. 179: 2020-2024.

Hu JJ, Smith TR, Miller MR, Mohrenweiser HW, Golden A, Douglas Case L. 2001. Amino acid substitution variants of APE1 and XRCC1 genes associated with ionizing radiation sensitivity, Carcinogenesis 22: 917-922.

ICRP Publication 118. 2012. Threshold doses for tissue reactions in a radiation protection context, Ann. ICRP 41.

ICRP. 2011. Radiological protection in fluoroscopically guided procedures performed outside the imaging department, Ann. ICRP, ICRP ref 4834-1783-0153

Jacob S, Boveda S, Bar O, Brézin A, Maccia C, Laurier D, Bernier MO. 2013. Interventional cardiologists and risk of radiationinduced cataract: results of a French multicenter observational study, Int. J. Cardiol. 167(5): 1843-7.

Lindh AR, Rafii S, Schultz N, Cox A, Helleday T. 2006. Mitotic defects in XRCC3 variants T241M and D213N and their relation to cancer susceptibility, Hum. Mol. Genet. 15: 1217-1224.

Lunn RM, Langlois RG, Hsieh LL, Thompson CL, Bell DA. 1999. XRCC1 polymorphisms: Effects on aflatoxin B1-DNA adducts and glycophorin A variant frequency, Cancer Res. 59: 2557-2561.

Maluf SW, Passos DF, Bacelar A, Speit G, Erdtmann B. 2000. Assessment of DNA damage in lymphocytes of workers exposed to X-radiation using the micronucleus test and the comet assay, Environ. Mol. Mutagen. 38: 311-315.

Matullo G, Palli D, Peluso M, Guarrera S, Carturan S, Celentano E, Krogh V, Munnia A, Tumino R, Polidoro S, Piazza A, Vineis P. 2001. XRCC1, XRCC3, XPD gene polymorphisms, smoking and (32)P-DNA adducts in a sample of healthy subjects, Carcinogenesis 22: 1437-1445.

Rastkhah E, Zakeri F, Ghoranneviss M, Rajabpour MR, Farshidpour MR, Mianji F, Bayat M. 2016. The cytokinesis-blocked micronucleus assay: dose-response calibration curve, background frequency in the population and dose estimation, Radiat. Environ. Biophys. 55: 41-51.

Sakly A, Ayed Y, Chaari N, Akrout M, Bacha H, Ben Cheikh H. 2013. Assessment of chromosomal aberrations and micronuclei in peripheral lymphocytes from Tunisian hospital workers exposed to ionizing radiation, Genet. Test. Mol. Biomarkers 17 (9):650-5.

Sari-Minodier I, Orsière T, Auquier P, Martin F, Botta A. 2007. Cytogenetic monitoring by use of the micronucleus assay among hospital workers exposed to low doses of ionizing radiation, Mutat. Res. 629: 111-121.

Song H, Ramus SJ, Quaye L, Dicioccio RA, Tyrer J, Lomas E, Shadforth D, Hogdall E, Hogdall C, McGuire V, Whittemore AS, Easton DF, Ponder BA, Kjaer SK, Pharoah PD, Gayther SA. 2006. Common variants in mismatch repair genes and risk of invasive ovarian cancer, Carcinogenesis 27: 22352242. 
Song YZ, Han FJ, Liu M, Xia CC, Shi WY, Dong LH. 2015. Association between single nucleotide polymorphisms in XRCC3 and radiation induced adverse effects on normal tissue: a meta analysis, PLOS ONE 10: 1-17.

Thierens H, Vral A. 2009. The micronucleus assay in radiation accidents, Ann. Ist. Super. Sani. 45: 260-264.

Wildinga SC, Reltona CL, Reesa GS, Taronec RE, Whitehousea CA, Tawna EJ. 2005. DNA repair gene polymorphisms in relation to chromosome aberration frequencies in retired radiation workers, Mutat. Res. 570: 137-145.
Yoshihara T, Ishida M, Kinomura A, Katsura M, Tsuruga T, Tashiro S, Asahara T, Miyagawa K. 2004. XRCC3 deficiency results in a defect in recombination and increased endoreduplication in human cells, Embo. J. 23: 670-680.

Zakeri F, Assaei RG. 2004. Cytogenetic monitoring of personnel working in angiocardiography laboratories in Iran hospitals, Mutat. Res. 562: 1-9.

Zakeri F, Hirobe T, Akbari Noghabi K. 2010. Biological effects of low-dose ionizing radiation exposure on interventional cardiologists, Occup. Med. 60: 464-469.

Cite this article as: Zakeri F, Farshidpour MR, Rajabpour MR. 2017. Occupational radiation exposure and genetic polymorphisms in DNA repair genes. Radioprotection 52(4): 241-249 